\title{
Topoisomerase-II Inhibitor
}

National Cancer Institute

\section{Source}

National Cancer Institute. Topoisomerase-II Inhibitor. NCI Thesaurus. Code C1968.

Any substance that inhibits topoisomerase-II, a topoisomerase that relieves torsional stress in a DNA molecule by cutting both strands of the DNA double helix. A topoisomerase II inhibitor can either stabilize the DNA-protein complex or inhibit the catalytic activity of the enzyme. Inhibition of topoisomerase-II causes DNA damage, inhibition of DNA replication, and apoptosis. 